Discussion Paper No. 07-020

\title{
The Returns to Pencil Use Revisited
}

\author{
Alexandra Spitz-Oener
}

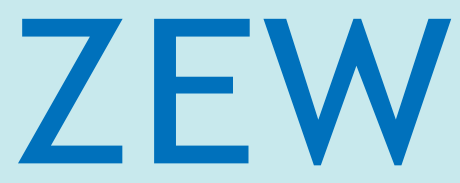

Zentrum für Europäische Wirtschaftsforschung $\mathrm{GmbH}$

Centre for European

Economic Research 
Discussion Paper No. 07-020

\title{
The Returns to Pencil Use Revisited
}

\author{
Alexandra Spitz-Oener
}

Download this ZEW Discussion Paper from our ftp server:

$\mathrm{ftp}: / / \mathrm{ftp} . z e w . d e / p u b / z e w-d o c s / d p / d p 07020 . p d f$

Die Discussion Papers dienen einer möglichst schnellen Verbreitung von neueren Forschungsarbeiten des ZEW. Die Beiträge liegen in alleiniger Verantwortung der Autoren und stellen nicht notwendigerweise die Meinung des ZEW dar.

Discussion Papers are intended to make results of ZEW research promptly available to other economists in order to encourage discussion and suggestions for revisions. The authors are solely responsible for the contents which do not necessarily represent the opinion of the ZEW. 


\section{Non-technical summary}

The increased diffusion of computers is one of the fundamental changes at workplaces in recent decades and research on the productivity increasing effects of computer use as well as on how computers have changed the demand for labor is now wide spread. However, research on the wage effect of computer use still remains controversial. In particular, as recent studies have called into question the ability to distinguish the effect of computers from other confounding factors. The most cited paper that challenges the "causality"interpretation of the positive wage mark-up for computer users relative to non-computer users is DiNardo and Pischke [1997], that also finds a positive correlation between wages and pencil use at the workplace.

Using the same data set as DiNardo and Pischke, but a more recent wave, this paper contributes to this discussion by showing that the pencil effect disappeared in 1998/99, whereas the computer effect is still present. Building on the task-based view of technological change, I demonstrate that computer users - but not pencil users - have experienced a pronounced shift towards analytical and interactive tasks. The results further suggest that computer users are rewarded for their higher levels of analytical and interactive task inputs in the labor market. 


\title{
THE RETURNS TO PENCIL USE REVISITED
}

\author{
Alexandra Spitz-Oener*
}

March 2007

\begin{abstract}
The increased diffusion of computers is one of the fundamental changes at workplaces in recent decades. While the majority of workers now spend a substantial fraction of their working day with a computer, research on the wage effect of computer use effectively came to a halt after DiNardo and Pischke [1997] found that wages were also positively associated with pencil use, calling into question the ability to distinguish the effect of computers from other confounding factors. Using the same data set as DiNardo and Pischke, but a more recent wave, this paper revitalizes the discussion by showing that the pencil effect disappeared in 1998/99, whereas the computer effect is still present. Computer users - but not pencil users - have experienced a pronounced shift towards analytical and interactive tasks, for which they are rewarded in the workplace.
\end{abstract}

JEL-classification: J31, C13,

Keywords: Computer wage differential, pencil wage differentials, changing skill requirements

*Humboldt University Berlin, ZEW and IZA; Spandauer Strasse 1, 10178 Berlin, Germany; Email: alexandra.spitz-oener@wiwi.hu-berlin.de. Phone: +49-30-2093-1679.

Acknowledgments: Part of the paper was written within the research project "ICT, Workplace Organization, and Wages Across and Within Skill Groups" commissioned by the Landesstiftung Baden-Württemberg foundation when the author worked in the ICT research group at ZEW Mannheim. Helpful comments by David Autor, Joshua Angrist, Irene Bertschek, Sandra Black, Francine Blau, Bernd Fitzenberger, Larry Kahn, Alan Krueger, and Susanne Prantl are gratefully acknowledged. 


\section{Introduction}

The widespread use of computers is one of the fundamental changes in industrial countries in recent decades. Today, there is a consensus that the implementation of computer technologies has changed skill requirements and hence the demand for labor. Because evidence suggests this change is skill-biased, computer use is also considered an important explanatory factor for the recent changes in the wage structure 11 Publications on wage differentials associated with on-the-job computer usage in the late-1990s, however, sounded the death knell for this body of literature, with probably the most cited criticisms of the "returns from computer use" literature coming from DiNardo and Pischke [1997], who show that there is also a considerable wage effect from the use of pencils (and other "white-collar" tools) in cross-section estimates. They argue that if we don't believe that pencils changed the wage structure, why should we believe that computers did?2

Using the same data set DiNardo and Pischke used, but a more recent cross-section, I show that the positive association between pencils and wages disappeared in 1998/99 while it is still present between computers and wages. This result then begs the question of why cross-section estimates suggested a positive association for both computers and pencils up to the late 1990s. While a major aim of this paper is to revitalize the discussion in this body of the literature, I also offer a speculative explanation. The explanation relies on a task-based view of technological change. As put forward by Spitz-Oener [2006], Autor et al. [2003] and Goos and Manning [2007] the "traditional" skill-biased techno-

\footnotetext{
${ }^{1}$ Comprehensive reviews of the skill-biased technological change literature can be found in Katz and Autor [1999], Chennells and van Reenen [1999] and Acemoglu [2002]. For a recent discussion see Autor, Katz and Kearney (2005b, 2005a). Autor, Levy and Murnane [2003] and Spitz-Oener [2006] provide evidence on how skill requirements in the workplace have changed in recent decades.

${ }^{2}$ For direct criticism of DiNardo and Pischke [1997] see Lang [2002]. The major argument is that computers can change the wage structure even if workers are not directly compensated for their computer use when computers are complementary with other skills. Autor, Katz and Krueger [1998] provide empirical evidence for this argument.
} 
logical change hypothesis is probably an insufficiently nuanced view of changes in the workplace associated with the recent diffusion of computer technologies. The argument is that computers substitute certain tasks - those that are expressible in rules and thus programmable (termed routine tasks)- whereas they complement workers in performing nonroutine analytic and nonroutine interactive tasks. One major result of this study is that computer users - but not pencil users - have experienced a pronounced shift towards analytical and interactive tasks between 1979 and 1998/99 for which they are rewarded in the workplace.

This paper is organized in 5 sections. In the next section, I review the related literature, present the data set and the variables of interest. Section III presents and discusses the estimation results. Section $[\mathrm{IV}$ offers a speculative explanation for the empirical finding. Section $\mathrm{V}$ concludes.

\section{Related Literature, Data and Empirical Framework}

Non-random assignment of computer technology to workers is the central theme in this body of the literature. Previous empirical studies have addressed the issue in one form or another. All of these studies consider observed differences between computer users and non-users, though there is a large difference with respect to the number of available observables in data sets. The methods used to account for unobserved heterogeneity range from including proxies for individual ability into the regression specification to applying panel data methods. $3^{3}$ The results are mixed, however, and depend largely on the underlying assumptions. The panel methods, for example, hinge crucially on the assumption of time-invariant unobserved heterogeneity. In the presence of changing returns on unobserved skills, differencing the data will not remove the wage effect of unobservables

\footnotetext{
${ }^{3}$ See Krueger [1993], who was the first to address the question of whether workers who use computers at work are paid more as a result of their computer skills or Entorf and Kramarz [1997] and Entorf, Gollac and Kramarz [1999], Bell [1996], who use panel data for France or the United Kingdom.
} 
that might be correlated with computer use. As DiNardo and Pischke [1997] already emphasized, this factor may be a plausible explanation for the differing results in panel analyzes for the United Kingdom and France - because the wage structure has widened in the United Kingdom since the early 1980s but not in France. An argument that also challenges the general credibility of panel estimates in this context is that identification in panel methods is through status changers, i.e. individuals that started or stopped using a computer. In the presence of downwardly rigid wages, panel methods lead to an underestimation of the computer wage effect.

Neither the DiNardo/Pischke-study nor the studies using panel data sets "prove" the computer coefficient to represent a pure selection effect. In contrast, the results are merely suggestive. Yet the findings have generally been interpreted as corroborating the notion that cross-section estimates are spurious. This is even more surprising as the major issue - non-random assignment - is a common problem in empirical research. One prominent example being the interpretation of estimates of the returns to education. In contrast to the returns-to-computer-use body of the literature, researchers have devoted a lot of effort to isolate the returns to education from the selection effect.

The analysis in this paper is based on the "Qualification and Career Survey", which is a survey of employees carried out by the German Federal Institute for Vocational Training (Bundesinstitut für Berufsbildung, BIBB) and the Research Institute of the Federal Employment Service (Institut für Arbeitsmarkt- und Berufsforschung, IAB). For most of the analysis, I use the latest cross-section, launched in 1998/99. It covers more than 30,000 individuals (men and women).4 DiNardo and Pischke [1997], in contrast, used cross-sections from 1979, 1985/86 and 1991/92.

In addition to the main variable of interest, computer use, three types of variables

${ }^{4}$ I restrict the sample to West German residents with German nationality: in other words, East German residents and non-German employees are excluded from the sample. Moreover, the sample does not include self-employed, employees with agricultural occupations and employees working in the agricultural sector. Persons younger than 18 or older than 65 are also excluded from the sample. 
are considered in the analyses: individual characteristics, company characteristics and workplace characteristics. I include variables reflecting individual characteristics in order to account for the fact that employees differ systematically with respect to characteristics that affect both computer use and wages. For example, as more highly educated workers are more likely to use computers at work and earn higher wages, I control for the level of formal education of employees, work experience and tenure with the current employer. As wages of civil servants are determined in a process that differs from the process for wages of employees in private companies, a dummy variable for civil servants is also included in the regressions.

One drawback of most estimates on individual-level data is that they generally do not provide information on employers. Employer information may however be important if it determines systematic effects on wages and computer use. The data set used in this study allows me to take various company characteristics into account such as company size, industry affiliation, innovation strategy and company performance. This ability is a substantial improvement over other studies in this area. Based on previous empirical research, I expect, for example, that larger companies and innovative companies pay higher wages and that they are more likely to use computer intensively.

Another feature that distinguishes this data set from others is that it includes information on the task composition of occupations.5 These tasks describe the occupational context in which computers are introduced. In addition, this information on occupational skill requirements allows me to further reduce unobserved heterogeneity.

The variables used in the estimates are constructed as follows (Summary statistics are in Table A in the Appendix A):

Hourly Wages: The survey contains information on monthly earnings, according to 18 categories. I assigned midpoints to each category which are then divided by the number

\footnotetext{
${ }^{5}$ For a detailed discussion of task measures and an analysis of how the task composition of occupations changed in West Germany since 1979 see Spitz-Oener [2006].
} 
of hours an individual usually spends at work. ${ }^{6}$ Compared to other data sets that are usually used in comparable analyzes such as the Current Population Survey for the United States or the IAB-Sample for Germany, this data set has the advantage that earnings of highly paid workers are not censored from above. In all estimates, the logarithm of wages is used as dependent variable. On average, employees in West Germany earned about 27 German Marks (about 16 US-Dollars) in 1998/99.

Computer equipment: The data set includes detailed information on the tools and machines used by the employees in the workplace. The "computer use" variable is a dummy that takes the value 1 if the employee uses a computer, terminal or electronic data processing device on the job. 57 percent of employees have used one or more of the above devices on the job in West Germany in 1998/99.

Individual characteristics: I distinguish three levels of formal education attained by employees. Employees with a low level of education are those with no vocational training. Employees with medium levels of education have a vocational qualification either from an apprenticeship or they have graduated from a vocational college. Employees holding a degree from a university or a technical college are classified as having a high level of education. As shown in Table A, the majority of the survey participants, 70 percent, has a medium qualification level, whereas 17 percent are highly qualified and only 12 percent have a low education level.

The survey participants also indicate their first year of work. Based on these answers, I calculate the years of (potential) work experience (1999 - first year of work). In addition, employees indicate the year when they started to work for the current employer. This information is used to calculate tenure (1999 - first year with current employer).

The data set includes information about previous unemployment spells (dummy variable: "Have you ever been unemployed before?"), marital status, gender and whether survey participants were born in East Germany. It also contains information about whether

\footnotetext{
${ }^{6}$ Comparable procedures are often used in literature, for example, by DiNardo and Pischke [1997] and by Entorf and Kramarz [1997].
} 
an employee is working as a civil servant. In addition, I constructed a dummy variable indicating whether employees live in a city (place of residence is larger than 100,000 inhabitants).

Workplace Characteristics: The analyses by Autor et al. [2003] and Spitz-Oener [2006] document how computer have changed the content of work towards analytical and interactive activities and away from manual and cognitive routine activities. The data set allows me to capture the content of jobs by considering task levels, and therefore, it gives a description of the context in which computers are used. Survey participants are asked what kind of activities they perform at the workplace. Based on these activities five categories are constructed, which classify the occupational skill requirements: analytic tasks, interactive tasks, repetitive cognitive tasks, repetitive manual tasks and non-repetitive manual tasks. Table 1 shows the list of activities that employees were asked for in the questionnaire and how the activities are classified in the five task categories. On the individual-level $i$, the task measures $\left(\operatorname{Task}_{i k}\right)$ are defined as:

(1) $\operatorname{Task}_{i k}=\frac{\text { number of activities in category } k \text { performed by } i \text { in } 1998 / 99}{\text { total number of activities in category } k \text { in } 1998 / 99} * 100$,

where $\mathrm{k}=1$ : non-routine analytic tasks; $\mathrm{k}=2$ : non-routine interactive tasks; $\mathrm{k}=3$ : routine cognitive tasks; $\mathrm{k}=4$ : routine manual tasks; $\mathrm{k}=5$ : non-routine manual tasks. For example, if the analytical task category includes 4 activities and employee $i$ performs 2 of them, the analytical task measure for employee $i$ is 50 .

The data set also contains information about the current occupation of the employees. Occupations are grouped according to the (2-digit) classification of occupational titles by the Federal Employment Bureau in 1999, leading to 78 occupational groups.

Company characteristics: Company size has been identified as an important component of wage determination in previous studies, finding that larger companies pay ceteris paribus higher wages. 7 In addition, computer use increases in company size (see Table B in Appendix A). Company size measured as the number of employees is captured by 7

\footnotetext{
${ }^{7}$ See, for example, Brown and Medoff, [1989], Schmidt and Zimmermann, [1991].
} 
size classes. Companies with one to four employees are classified to belong to the first size bracket and companies with more than 1,000 employees to the last one. Based on these size classes, 7 dummy variables are formed. Most of the survey participants, 28 percent, belong to companies with a size class from 10 up to 49 employees, followed by the size class from 100 up to 499 employees. Companies with more than 1000 employees are represented by 12 percent of the survey participants. About 20 percent of the interviewed employees belong to small companies with less than ten employees.

The data set also includes information about the performance of companies. The survey participants were asked whether the company was doing very good, good, rather bad or bad. For each of these categories, I constructed a dummy variable. Table A shows that 18 percent of employees report to work in companies that are doing very well and 65 percent work in companies that are doing well. 17 percent of employees work in companies that are either doing rather bad or bad.

Companies are classified according to 48 detailed industry codes. Based on these codes I group companies into three sectors: manufacturing, trade, and services 8 The inclusion of these variables accounts for inter-industry wage differentials that are not already captured by the observed individual and company characteristics.9

\section{Empirical Results}

The most cited criticisms of the "returns from computer use" literature comes from DiNardo and Pischke [1997] who show that there is also a considerable wage effect of the use of pencils (and other "white-collar" tools) in their cross-section estimates. Table 2 , column 1-3, reports parts of their Table III. Panel A reports the coefficients for computer use when separate regressions are performed for each workplace tool. Panel B shows

\footnotetext{
${ }^{8} \mathrm{I}$ also ran regressions that included more detailed industry dummies. The results that I report in Section [II are robust to this change in specification.

${ }^{9}$ See, for example, Krueger and Summers, [1987], Dickens and Katz, [1987], Gibbons and Katz, [1992] and Abowd, Kramarz and Margolis, [1999].
} 
the results when all tools are included together in the specification. Controlling for the different workplace tools attenuates the coefficient for computer use in each period.

I reproduced their estimates for the most recent wave of the data set (Table 2, last column). Relative to the result in Panel A, the estimated coefficient for computer use decreases by around 30 percent due to the inclusion of the dummies for the different workplace tools (Panel B). The coefficient of computer use still has a magnitude of around 15 percent. In contrast to the previous years, in which the different tools have always had a significant positive impact on wages, only the coefficients for the use of calculators and working while sitting remain significantly positive in 1998/99. The coefficient for using a pencil is insignificant and using a telephone at work is now significantly negatively correlated with wages. In what follows, I analyze this pattern in more detail.10

Table 3, columns (1)-(5), display the estimation results of "standard" wage regressions. Unreported results show that the raw log wage differential for computer use in Germany is 0.275 (about 31 percent) in 1998/99. This figure is slightly lower than the raw log wage differential of 0.288 that DiNardo and Pischke [1997] report for Germany based on the 1991/92 cross-section of the BIBB/IAB data. Thus, in contrast to the period between 1979 and 1991/92, when the raw log wage differentials for computer use increased steadily (although at a declining pace), as shown in the paper by DiNardo and Pischke, this differential remained stable or even declined slightly in the 1990s.

Columns (1)-(5) show the results of specifications that are successively extended with additional controls. Including individual characteristics such as the level of formal education, work experience, tenure, gender, marital status or residence in a city reduces the coefficient of computer use by more than 30 percent (column 1). The coefficients of the controls have the expected sign, therefore I will not discuss them in detail. The results can, however, be found in Table C in Appendix A. In column (2), workplace characteristics are included in the specification. The higher the measure is for non-routine cognitive

\footnotetext{
${ }^{10}$ The correlation between tools ranges from 0.007 (between work while witting and pencil use) to 0.350 (between work while sitting and computer use).
} 
activities, both analytical and interactive, the higher the wages are. By contrast, wages decrease in the measure for non-routine manual activities. Including the workplace characteristics additionally reduces the computer coefficient by 30 percent (compared to the coefficient in column 1). In column (3), company characteristics such as company size and information about the innovation strategy of the company are included in order to control, for example, for company size effects in remuneration. Industry dummies are also included to account for cross-sectoral differences in computer usage and pay. In addition, dummies indicating company performance are included. Most interestingly, the inclusion of the company characteristics hardly affect the computer coefficient. By contrast, the returns to education decreased and the dummy for employees born in East Germany as well as the dummy for employees living in the city now are insignificant. Column (4) includes 10 dummies for West German states that control for cross-state differences in wage levels owing to, for example, differing economic conditions. These variables neither affect the computer coefficient nor the coefficients of the other controls. The specification in column (5) includes 77 two-digit occupation dummies. The occupation dummies have a large impact on the estimated computer wage differential. The inclusion of the occupation dummies in the specification is warranted as one major aim of this exercise is to show that the estimated computer coefficient is robust to the inclusion of as many controls as possible. However, the occupation dummies also bear the notion of over-controlling which should be kept in mind when interpreting the size of coefficients.

From column (1) to column (5), the computer coefficient drops by more than 70 percent, indicating that the largest part of the raw logarithm wage differential for computer users has been due to observable differences that would have resulted in employees earning different wages even in the absence of computers. The results indicate that observable workplace characteristics such as workplace tasks account for the largest proportion of the bias in the raw logarithm wage differential. Conditional on all the controls, however, the results still suggest that employees who use computer on the job earn around 8 percent 
higher wages. Without occupation controls the coefficient is even 0.122 .11

Ideal control variables are only those that are attributes of the assignment to computer use and the earnings process but are unaffected by the treatment itself (for example, time-invariant individual characteristics such as gender and place of birth). Some of the controls used in this study, such as work experience or the incidence of previous periods of unemployment, might be affected by the treatment. Computer users are, for example, less likely to become unemployed. Therefore, the treatment effect estimated here does not capture the indirect effects of computer use on wages (for example, through productivity).

In columns (6) and (7) I use a less restrictive specification that includes interactions between all covariates $X$ (previously demeaned using sample averages) and the computer use dummy $D_{i}$. Hence, in contrast to the previous regressions, the coefficient on computer use is not constrained to be homogeneous on average conditional on the observable variables. Although the previous specifications already include a large number of controls, the remaining 13 (8) percent wage markup for computer users may still be due to characteristics that are not observable in the data set at hand if these unobservables are positively correlated with both computer use and wages. The aim of this approach, often termed regression based matching or fully interacted linear matching, is to purge the specification from the remaining covariance between unobservables and computer use. ${ }^{12}$ The specification in column (6) does not include occupation dummies, whereas the specification in column (7) includes occupation dummies. The results in column (6) show that including the interaction terms reduces the estimated coefficient of computer use slightly to 0.120 percent (=average treatment effect, ATE). The interaction terms are jointly significant $\left(F_{(41,8852)}=3.24, p=0.0000\right)$ and therefore provide evidence of the presence of heteroge-

\footnotetext{
${ }^{11}$ Unreported results show that the main conclusions from these regressions do not change when using a consistent sample of 8936 observations (column 4). The raw log wage differential then is 0.248 , the coefficient of specification (1) even increases to 0.216 and the coefficient of column (2) increases to 0.171 . All being significant at the 1 percent level.

${ }^{12}$ See Wooldridge [2002], Chapter 18.
} 
neous effects. ${ }^{13}$ Table 4 shows the results for selected interaction terms. The empirical evidence suggests, for example, that computer users with a university degree or with high levels of analytical tasks benefit particularly in terms of wages. Differences in gender, by contrast, do not have a significant effect on the gains from computer use.

The estimated average treatment effect for the treated (ATT) is $0.138 \quad($ S.E. $=0.020)$ based on this regression, which is significantly different to the ATE $[14$ On average, treatment effect heterogeneity seems to be important. The result that the ATT is higher than the ATE suggests that there has been selection into treatment based on expected returns. If computer non-user had started to use computer instead of those who actually did, they would have enjoyed a significantly lower benefit.15

Column (7) shows the results when occupation dummies are inlcuded as additional controls. This again reduces the estimated coefficient considerably; the ATE now being 0.061. The interaction terms are again jointly significant $\left(F_{(112,8666)}=8.34, p=0.0000\right)$. The estimated ATT is 0.083 based on this regression. As in column (6), the ATT and ATE are significantly different from each other.

As heterogeneous treatment effects appear to be important, results might differ de-

\footnotetext{
${ }^{13}$ The standard errors in column (6) and (7) are estimated using a design-matrix bootstrap approach in order to account for the generated regressors in the specification. Because of the large number of dummy variables in the specification the resamples are chosen to be twice as large as the sample in order to guarantee that all coefficients can be estimated. The estimated covariance matrix then is doubled in accordance with the rate of convergence of the estimator.

${ }^{14} A \hat{T} T=A \hat{T} E+\left(\sum_{i=1}^{N} D_{i}\right)^{-1}\left(\sum_{i=1}^{N} D_{i}(X-\bar{X}) \hat{\delta}\right) . D_{i}=1$ indicates that employee $i$ uses a computer on the job, and $D_{i}=0$ that employee $i$ does not. $D_{i}(X-\bar{X})$ are the interaction terms between computer use and all the level variables $X$, where all the $X$ had previously been demeaned by the sample averages. The $\hat{\delta}$ are the estimated coefficients of the interaction terms.

${ }^{15}$ The main focus of previous studies was on the ATE, thereby neglecting the potential of parameter heterogeneity. In a recent contribution, Dolton and Makepeace [2004] provide evidence for the importance of parameter heterogeneity. By allowing for variation in the parameter values, they find in their panel data set that some individuals benefit from computer usage in the United Kingdom. My approach of estimating the ATT is more general than the approach Dolton and Makepeace [2004] are taking.
} 
pending on the particular assumptions made and assumptions on out of the sample predictions are particularly important in this respect. As a robustness test I therefore also did matching on the propensity score that imputes the expected non-treatment outcome for a computer user with observable characteristics $\mathrm{X}$ by the fitted value of a nonparametric regression in the sample of computer non-users with similar X. The details on the matching estimates can be found in Appendix B. The overall conclusions are, however, that the results are invariant to the particular estimation approach taken.

I now take up the DiNardo and Pischke [1997] idea and estimate regressions that include dummies indicating the use of various workplace tools instead of the computer dummy. A subsample of these results, those for pencil use, are shown in Table 5. Unreported results show that the first-order relationship between pencil use and wages is 5.7 percent (significant at the 1-percent level). Similar to the specifications in Table 3, I successively augment the specifications with additional controls. In contrast to the computer effect, the estimated pencil effect disappears as soon as controls for individual and workplace characteristics are included in the specification (column 2) ${ }^{16}$ The variables that have had only attenuating effects on the coefficient of computer use, now result in the pencil effect disappearing, and it takes very view controls to do so. Column (2) shows the results of the regression specification including the minimum number of controls that are necessary to eliminate the wage effect of pencil use. It is interesting to notice that the coefficient in the comparable computer equation (Table 3, column 2) still is about 12 percent.

\section{A speculative explanation}

Why do the results for 1998/99 differ from results for previous years? One possible explanation is that changes in occupational skill requirements have evolved differently for computer and pencil users. ${ }^{17}$

\footnotetext{
${ }^{16}$ The detailed results are shown in Table D in Appendix A.

${ }^{17}$ DiNardo and Pischke [1997] noted that the computer coefficient increases strongly over time when all tools are entered in the regression together while some of the coefficients of the other tools tend to fall over
} 
As put forward by Autor et al. [2003] and Spitz-Oener [2006] the "traditional" skillbiased technological change hypothesis is probably an insufficiently nuanced view of changes in the workplace associated with the recent diffusion of computer technologies. The argument is that computers substitute certain tasks - those that are expressible in rules and thus programmable (termed routine tasks)- whereas they complement workers in performing nonroutine analytic and nonroutine interactive tasks. In contrast to this reasoning, I expect pencils neither to substitute for nor to complement certain tasks.

For this part of the analyses I use all 4 waves of the data set, that is $1979,1985 / 86$, 1991/92 and 1998/99. Table 6 shows how both changes in computer use (Panel A) and pencil use (Panel B) are related to changes in the task composition of occupations in recent decades. ${ }^{18}$ Each column represents a separate OLS regression of the annualized changes in occupational task inputs on the annual changes in occupational computer use or the annual changes in occupational pencil use, respectively. Annual changes are calculated between successive waves, that is between 1979 and 1985/86, between 1985/86 and 1991/92, and between 1991/92 and 1998/99. The regressions are then performed on the stacked data set. The specifications all include time dummies for 1985/86-1991/92 and 1991/92-1998/99 in order to control for within occupational trends in task changes for the corresponding time period relative to the base period 1979-1985/86.

While the results shown in Panel A indicate that occupations that saw greater increases in computerization witnessed significantly larger increases in analytical and interactive task inputs and greater declines in routine manual and routine cognitive task requirements, the results in Panel $\mathrm{B}$ are quite different. Two of the five equations turn out to be insignificant: the relationship between changes in pencil use and changes in analytic time. They concluded that this might indicate that the role of computers in the workplace is changing. While this view is plausible as changes in computer technology itself (in particular the convergence of information and communication technologies) have certainly altered its role in the workplace, the explanation that I am going to outline here relies on recent research investigating changes in occupational skill requirements owing to computerization.

${ }^{18}$ Panel A is from Spitz-Oener [2006], Table 6. 
and routine manual activities. Besides, the coefficients of the interactive and nonroutine manual equation are significantly negative and the coefficient of the routine cognitive equation is significantly positive. Thus, it turns out that these occupations have shifted away from interactive tasks towards more routine cognitive tasks.

An inspection of underlying occupations shows that computer user and pencil user belonged to a very similar set of occupations in 1979. Examples are office workers, technicians and sales clerks. By 1998/99, however, these two groups work in different occupations. Examples of typical occupations of computer user are still office workers, technicians and sales clerks - thus the same as for both groups in 1979. Pencils user, in contrast, appear more frequently in crafts occupations such as mechanics, electricians and masons or in health care such as nurses and masseurs.

Table 7 shows OLS regressions of log hourly wages on task inputs. The estimated coefficients may be interpreted as task prices. Column (1) shows the results without additional controls. The coefficients for analytical, interactive and routine cognitive tasks are significantly positive, whereas the coefficients for manual tasks are significantly negative. The size of coefficients drop when a dummy for computer usage is included in the specification (column 2). The task prices for analytical and interactive tasks are, however, still significantly positive, while the coefficient for the routine cognitive task category now is insignificant. Comparing these results with those in column (3) and (4) shows that the inclusion of additional controls don't affect the estimates much for the computer coefficient and the coefficients of the analytical and interactive task measure. Whereas the coefficient for the routine cognitive task measure now is insignificant. In column (5) I additionally include interaction terms between the task measures and the computer use dummy in order to test for complementarities in wages. This reduces both the level and significance of the task measures and only the coefficients for analytical and interactive activities remain significantly positive related to wages. Most of the interaction terms are insignificant, however. The exception being the interaction between the analytical task measure and computer usage, which suggests a complementary relationship between 
the two variables. In addition, while the level effect of non-routine manual tasks now is insignificant, computer users tend to have lower wages the larger their measure in non-routine manual tasks.

\section{Conclusions}

Non-random assignment is the major issue in empirical research. The body of the literature that investigates the causal effects of education on earnings, for example, is huge. Research on the causal effects of computer use on earning, by contrast, came merely to a halt after DiNardo and Pischke [1997].

Using the same data set DiNardo and Pischke [1997] used, but a more recent wave, provides opportunity to revitalize the discussion on whether computer users earn higher wages than employees who do not use computers on the job. In contrast to their findings for earlier years, I show that the positive association between wages and pencils disappeared in 1999 while it is still present for computer usage.

I offer a speculative explanation for the findings. The explanation relies on a taskbased view of technological change and focuses on changes in skill requirements brought about by the introduction of computer technologies in the workplace. The argument is that computers substitute certain tasks - those that are expressible in rules and thus programmable (termed routine tasks)- whereas they complement workers in performing nonroutine analytic and nonroutine interactive tasks. Previous work already demonstrated the pronounced shifts away from cognitive and manual routine tasks towards analytical and interactive tasks owing to computerization [Spitz-Oener, 2006, Autor et al., 2003]. This study shows that computer users and pencil users performed similar tasks in the workplace in 1979 but by 1999 their activities had diverged. In contrast to pencil users, computer users have experienced a pronounced shift towards analytical and interactive tasks between 1979 and 1998/99 for which they are rewarded in the workplace. 


\section{Appendix A}

Table A: Summary Statistics

\begin{tabular}{|c|c|c|c|c|c|}
\hline & Mean & Std. Deviation & Min. & Max. & Observations \\
\hline computer & 0.57 & 0.50 & 0 & 1 & 21816 \\
\hline Pencil & 0.92 & 0.27 & 0 & 1 & 18775 \\
\hline (hourly) wages (in DM) & 27.19 & 11.82 & 3.13 & 98.68 & 18561 \\
\hline \multicolumn{6}{|l|}{ Qualification } \\
\hline high education level & 0.17 & 0.37 & 0 & 1 & 21816 \\
\hline medium education level & 0.71 & 0.46 & 0 & 1 & 21816 \\
\hline low education level & 0.12 & 0.33 & 0 & 1 & 21816 \\
\hline experience & 20.76 & 11.58 & 0 & 47 & 21816 \\
\hline tenure & 11.75 & 9.84 & 0 & 47 & 21816 \\
\hline \multicolumn{6}{|l|}{ Workplace Characteristics: } \\
\hline analytic task measure & 14.01 & 23.80 & 0 & 100 & 18041 \\
\hline interactive task measure & 30.26 & 28.18 & 0 & 100 & 21754 \\
\hline repetitive cognitive task measure & 21.73 & 41.24 & 0 & 100 & 21813 \\
\hline repetitive manual task measure & 17.43 & 30.83 & 0 & 100 & 21768 \\
\hline non-repetitive manual task measure & 24.32 & 24.99 & 0 & 50 & 12319 \\
\hline \multicolumn{6}{|l|}{ Company Characteristics } \\
\hline product innovation & 0.37 & 0.48 & 0 & 1 & 20802 \\
\hline process innovation & 0.51 & 0.50 & 0 & 1 & 20857 \\
\hline very good company performance & 0.18 & 0.39 & 0 & 1 & 14450 \\
\hline good company performance & 0.65 & 0.48 & 0 & 1 & 14450 \\
\hline rather bad company performance & 0.14 & 0.35 & 0 & 1 & 14450 \\
\hline bad company performance & 0.03 & 0.17 & 0 & 1 & 14450 \\
\hline \multicolumn{6}{|l|}{ Other Controls } \\
\hline ever unemployed & 0.30 & 0.46 & 0 & 1 & 22545 \\
\hline married & 0.69 & 0.46 & 0 & 1 & 22677 \\
\hline civil servants & 0.11 & 0.31 & 0 & 1 & 22677 \\
\hline born in East Germany & 0.04 & 0.19 & 0 & 1 & 22677 \\
\hline woman & 0.44 & 0.50 & 0 & 1 & 22677 \\
\hline lives in city & 0.38 & 0.48 & 0 & 1 & 22677 \\
\hline
\end{tabular}


Table B: Computer Usage by Company Size Distribution

\begin{tabular}{lccc}
\hline No. of employees & Freq. & Percent & $\begin{array}{c}\text { computer usage } \\
\text { (in percent) }\end{array}$ \\
\hline \hline 1 to 4 & 1,707 & 7.8 & 42.9 \\
5 to 9 & 2,716 & 12.3 & 45.3 \\
10 to 49 & 6,186 & 28.1 & 50.1 \\
50 to 99 & 2,790 & 12.7 & 57.1 \\
100 to 499 & 4,457 & 20.2 & 63.8 \\
500 to 999 & 1,447 & 6.6 & 68.3 \\
1000 and more & 2,721 & 12.4 & 72.1 \\
\hline Total & 22,024 & & \\
\hline \hline
\end{tabular}


Table C: OLS Regressions for the Effect of Computer Use on Wages

\begin{tabular}{|c|c|c|c|c|c|c|c|}
\hline \multicolumn{8}{|c|}{ Dependent Variable: Log(Hourly Wages) } \\
\hline & $(1)$ & $(2)$ & (3) & (4) & $(5)$ & (6) & $(7)$ \\
\hline \multirow[t]{2}{*}{ computer } & $0.182^{* * *}$ & $0.123^{* * *}$ & $0.122^{* * *}$ & $0.122^{* * *}$ & $0.076^{* * *}$ & $0.120^{* * *}$ & $0.061^{* * *}$ \\
\hline & $(0.005)$ & $(0.006)$ & $(0.008)$ & $(0.008)$ & $(0.010)$ & $(0.020)$ & $(0.024)$ \\
\hline \multicolumn{8}{|c|}{ Individ. Characteristics } \\
\hline \multirow[t]{2}{*}{ high educ. level } & $0.437^{* * *}$ & $0.379^{* * *}$ & $0.330^{* * *}$ & $0.329^{* * *}$ & $0.222^{* * *}$ & $0.206^{* * *}$ & * 0.089 \\
\hline & $(0.011)$ & $(0.014)$ & $(0.018)$ & $(0.018)$ & $(0.020)$ & $(0.049)$ & $(0.068)$ \\
\hline \multirow[t]{2}{*}{ medium educ. level } & $0.126^{* * *}$ & $0.102^{* * *}$ & $0.083^{* * *}$ & $0.082^{* * *}$ & $0.052^{* * *}$ & $0.081^{* * *}$ & $0.042^{* *}$ \\
\hline & $(0.009)$ & $(0.011)$ & $(0.014)$ & $(0.014)$ & $(0.014)$ & $(0.017)$ & $(0.024)$ \\
\hline \multirow[t]{2}{*}{ experience } & $0.017^{* * *}$ & $0.018^{* * *}$ & $0.018^{* * *}$ & $0.017^{* * *}$ & $0.017^{* * *}$ & $0.013^{* * *}$ & $0.014^{* * *}$ \\
\hline & $(0.001)$ & $(0.001)$ & $(0.001)$ & $(0.001)$ & $(0.001)$ & $(0.002)$ & $(0.003)$ \\
\hline \multirow[t]{2}{*}{ experience $^{2} *(1 / 100)$} & $-0.000^{* * *}$ & $-0.000^{* * *}$ & $-0.000^{* * *}$ & $-0.000^{* * *}$ & $-0.000^{* * *}$ & -0.000 & -0.000 \\
\hline & $(0.000)$ & $(0.000)$ & $(0.000)$ & $(0.000)$ & $(0.000)$ & $(0.000)$ & $(0.000)$ \\
\hline \multirow[t]{2}{*}{ tenure } & $0.009^{* * *}$ & $0.008^{* * *}$ & $0.006^{* * *}$ & $0.006^{* * *}$ & $0.005^{* * *}$ & $0.005^{* * *}$ & $0.005^{* * *}$ \\
\hline & $(0.000)$ & $(0.000)$ & $(0.000)$ & $(0.000)$ & $(0.000)$ & $(0.001)$ & $(0.001)$ \\
\hline \multirow[t]{2}{*}{ woman } & $-0.092^{* * *}$ & $-0.083^{* * *}$ & $-0.098^{* * *}$ & $-0.098^{* * *}$ & $-0.088^{* * *}$ & $-0.122^{* * *}$ & $-0.110^{* * *}$ \\
\hline & $(0.009)$ & $(0.010)$ & $(0.013)$ & $(0.014)$ & $(0.014)$ & $(0.022)$ & $(0.037)$ \\
\hline \multirow[t]{2}{*}{ married } & $0.105^{* * *}$ & $0.097^{* * *}$ & $0.088^{* * *}$ & $0.088^{* * *}$ & $0.083^{* * *}$ & $0.086^{* * *}$ & $0.082^{* * *}$ \\
\hline & $(0.008)$ & $(0.008)$ & $(0.010)$ & $(0.010)$ & $(0.010)$ & $(0.015)$ & $(0.020)$ \\
\hline \multirow[t]{2}{*}{ woman*married } & $-0.120^{* * *}$ & $-0.107^{* * *}$ & $-0.104^{* * *}$ & $-0.103^{* * *}$ & $-0.105^{* * *}$ & $-0.129^{* * *}$ & $-0.120^{* * *}$ \\
\hline & $(0.011)$ & $(0.012)$ & $(0.012)$ & $(0.016)$ & $(0.015)$ & $(0.025)$ & $(0.032)$ \\
\hline \multirow[t]{2}{*}{ ever unemployed } & $-0.022^{* * *}$ & $-0.024^{* * *}$ & $-0.037^{* * *}$ & $-0.037^{* * *}$ & $-0.036^{* * *}$ & -0.004 & -0.008 \\
\hline & $(0.006)$ & $(0.007)$ & $(0.008)$ & $(0.008)$ & $(0.008)$ & $(0.012)$ & $(0.020)$ \\
\hline \multirow[t]{2}{*}{ born in East Germany } & $-0.045^{* * *}$ & $-0.031^{* *}$ & -0.021 & -0.019 & -0.015 & 0.007 & 0.004 \\
\hline & $(0.013)$ & $(0.015)$ & $(0.018)$ & $(0.018)$ & $(0.014)$ & $(0.026)$ & $(0.037)$ \\
\hline \multirow[t]{2}{*}{ civil servant } & $-0.064^{* * *}$ & $-0.076^{* * *}$ & $-0.094^{* *}$ & $-0.094^{* *}$ & $-0.107^{* * *}$ & 0.015 & 0.003 \\
\hline & $(0.009)$ & $(0.009)$ & $(0.041)$ & $(0.041)$ & $(0.045)$ & $(0.079)$ & $(0.103)$ \\
\hline \multirow[t]{2}{*}{ lives in city } & $0.016^{* * *}$ & $0.014^{* *}$ & 0.008 & 0.005 & 0.002 & 0.002 & -0.000 \\
\hline & $(0.005)$ & $(0.006)$ & $(0.007)$ & $(0.008)$ & $(0.008)$ & $(0.013)$ & $(0.020)$ \\
\hline
\end{tabular}

$<$ Table continues on next page $>$ 
Dependent Variable: Log(Hourly Wages)

\begin{tabular}{|c|c|c|c|c|c|c|c|}
\hline & $(1)$ & $(2)$ & $(3)$ & $(4)$ & $(5)$ & $(6)$ & $(7)$ \\
\hline \multicolumn{8}{|l|}{ Company Characteristics } \\
\hline \multirow[t]{2}{*}{ product innovation } & & & 0.004 & 0.004 & 0.008 & 0.010 & 0.016 \\
\hline & & & $(0.008)$ & $(0.008)$ & $(0.007)$ & $(0.012)$ & $(0.016)$ \\
\hline \multirow[t]{2}{*}{ process innovation } & & & $0.036^{* * *}$ & $0.034^{* * *}$ & $0.025^{* * *}$ & $0.024^{* *}$ & 0.018 \\
\hline & & & $(0.008)$ & $(0.008)$ & $(0.008)$ & $(0.012)$ & $(0.016)$ \\
\hline \multirow[t]{2}{*}{ very good company performance } & & & $0.044^{* *}$ & $0.038^{*}$ & $0.045^{* *}$ & -0.021 & -0.017 \\
\hline & & & $(0.026)$ & $(0.021)$ & $(0.022)$ & $(0.033)$ & $(0.046)$ \\
\hline \multirow[t]{2}{*}{ good company performance } & & & 0.007 & 0.003 & 0.010 & -0.031 & -0.025 \\
\hline & & & $(0.025)$ & $(0.020)$ & $(0.020)$ & $(0.030)$ & $(0.046)$ \\
\hline \multirow[t]{2}{*}{ rather bad company performance } & & & -0.012 & -0.016 & -0.011 & -0.025 & -0.027 \\
\hline & & & $(0.021)$ & $(0.021)$ & $(0.021)$ & $(0.032)$ & $(0.046)$ \\
\hline \multicolumn{8}{|c|}{ Workplace Characteristics: Measure of... } \\
\hline \multirow[t]{2}{*}{ non-routine analytic tasks } & & $0.087^{* * *}$ & $0.120^{* * *}$ & $0.120^{* * *}$ & $0.077^{* * *}$ & 0.057 & 0.048 \\
\hline & & $(0.012)$ & $(0.016)$ & $(0.016)$ & $(0.016)$ & $(0.036)$ & $(0.060)$ \\
\hline \multirow[t]{2}{*}{ non-routine interactive tasks } & & $0.154^{* * *}$ & $0.154^{* * *}$ & $0.155^{* * *}$ & $0.150^{* * *}$ & 0.193 & 0.179 \\
\hline & & $(0.011)$ & $(0.014)$ & $(0.014)$ & $(0.015)$ & $(0.026)$ & $(0.036)$ \\
\hline \multirow[t]{2}{*}{ routine cognitive tasks } & & $0.031^{* * *}$ & 0.005 & 0.004 & -0.001 & -0.003 & -0.002 \\
\hline & & $(0.012)$ & $(0.014)$ & $(0.014)$ & $(0.014)$ & $(0.018)$ & $(0.028)$ \\
\hline \multirow[t]{2}{*}{ routine manual tasks } & & -0.006 & $-0.040^{* *}$ & $-0.037^{* *}$ & $-0.033^{*}$ & -0.040 & -0.043 \\
\hline & & $(0.017)$ & $(0.018)$ & $(0.018)$ & $(0.020)$ & $(0.024)$ & $(0.041)$ \\
\hline \multirow[t]{2}{*}{ non-routine manual tasks } & & $-0.119^{* * *}$ & $-0.096^{* * *}$ & $-0.095^{* * *}$ & $-0.083^{* * *}$ & -0.032 & -0.041 \\
\hline & & $(0.011)$ & $(0.014)$ & $(0.014)$ & $(0.014)$ & $(0.022)$ & $(0.036)$ \\
\hline 77 occupation dummies & No & No & No & No & Yes & No & Yes \\
\hline 7 company size dummies & No & No & Yes & Yes & Yes & Yes & Yes \\
\hline dummies for manufacturing \& trade & No & No & Yes & Yes & Yes & Yes & Yes \\
\hline 10 dummies for West German states & No & No & No & Yes & Yes & Yes & Yes \\
\hline computer $*[x-E(x)]$ & No & No & No & No & No & Yes & Yes \\
\hline $\mathrm{R}^{2}$ & 0.348 & 0.340 & 0.399 & 0.401 & 0.443 & 0.410 & 0.455 \\
\hline Number of observations & 18547 & 15266 & 8936 & 8936 & 8897 & 8936 & 8897 \\
\hline
\end{tabular}

Employees with low levels of education working in large companies in the services sector are the base category. Heteroscedasticity-consistent standard errors are in parentheses in column (1)-(5). Column (6) and (7): computer $*[x-E(x)]$ means that the specification includes interaction terms between computer use and all the level variables $X$, where all the $X$ had previously been demeaned by the sample averages. Bootstrapped standard errors using 100 resamples. ${ }^{* * *},{ }^{* *},{ }^{*}$-indicate significance at the $1,5,10$ percent level. 
Table D: OLS Regressions for the Effect of Pencil Use on Wages

\begin{tabular}{|c|c|c|c|c|c|}
\hline \multicolumn{6}{|c|}{ Dependent Variable: Log(Hourly Wages) } \\
\hline & (1) & $(2)$ & $(3)$ & $(4)$ & (5) \\
\hline \multirow[t]{2}{*}{ Pencil } & $0.033^{* * *}$ & 0.016 & 0.016 & 0.016 & 0.005 \\
\hline & $(0.010)$ & $(0.011)$ & $(0.013)$ & $(0.013)$ & $(0.013)$ \\
\hline \multicolumn{6}{|c|}{ Individ. Characteristics } \\
\hline \multirow[t]{2}{*}{ high educ. level } & $0.495^{* * *}$ & $0.398^{* * *}$ & $0.358^{* * *}$ & $0.357^{* * *}$ & * $0.231^{* * *}$ \\
\hline & $(0.013)$ & $(0.015)$ & $(0.020)$ & $(0.020)$ & $(0.021)$ \\
\hline \multirow[t]{2}{*}{ medium educ. level } & $0.151^{* * *}$ & $0.112^{* * *}$ & $0.096^{* * *}$ & * $0.095^{* * *}$ & * $0.057^{* * *}$ \\
\hline & $(0.011)$ & $(0.013)$ & $(0.016)$ & $(0.016)$ & $(0.016)$ \\
\hline \multirow[t]{2}{*}{ experience } & $0.018^{* * *}$ & $0.019^{* * *}$ & $0.017^{* * *}$ & $0.017^{* * *}$ & * $0.018^{* * *}$ \\
\hline & $(0.001)$ & $(0.001)$ & $(0.001)$ & $(0.001)$ & $(0.001)$ \\
\hline \multirow[t]{2}{*}{ experience $^{2} *(1 / 100)$} & $-0.000^{* * *}$ & $-0.000^{* * *}$ & $-0.000^{* * *}$ & $-0.000^{* * *}$ & $-0.000^{* * *}$ \\
\hline & $(0.000)$ & $(0.000)$ & $(0.000)$ & $(0.000)$ & $(0.000)$ \\
\hline \multirow[t]{2}{*}{ tenure } & $0.009^{* * *}$ & $0.008^{* * *}$ & $0.005^{* * *}$ & * $0.006^{* * *}$ & * $0.005^{* * *}$ \\
\hline & $(0.000)$ & $(0.000)$ & $(0.001)$ & $(0.001)$ & $(0.001)$ \\
\hline \multirow[t]{2}{*}{ woman } & $-0.079^{* * *}$ & $-0.075^{* * *}$ & $-0.088^{* * *}$ & $-0.089^{* * *}$ & $-0.095^{* * *}$ \\
\hline & $(0.010)$ & $(0.011)$ & $(0.014)$ & $(0.014)$ & $(0.015)$ \\
\hline \multirow[t]{2}{*}{ married } & $0.120^{* * *}$ & $0.103^{* * *}$ & $0.091^{* * *}$ & * $0.091^{* * *}$ & * $0.086^{* * *}$ \\
\hline & $(0.009)$ & $(0.009)$ & $(0.011)$ & $(0.011)$ & $(0.011)$ \\
\hline \multirow[t]{2}{*}{ woman*married } & $-0.119^{* * *}$ & $-0.101^{* * *}$ & $-0.095^{* * *}$ & $-0.093^{* * *}$ & $-0.098^{* * *}$ \\
\hline & $(0.012)$ & $(0.013)$ & $(0.017)$ & $(0.017)$ & $(0.016)$ \\
\hline \multirow[t]{2}{*}{ ever unemployed } & $-0.036^{* * *}$ & $-0.033^{* * *}$ & * $-0.046^{* * *}$ & $-0.046^{* * *}$ & $-0.044^{* * *}$ \\
\hline & $(0.007)$ & $(0.007)$ & $(0.009)$ & $(0.009)$ & $(0.008)$ \\
\hline \multirow[t]{2}{*}{ born in East Germany } & $-0.056^{* * *}$ & $-0.035^{* *}$ & -0.024 & -0.023 & -0.010 \\
\hline & $(0.015)$ & $(0.015)$ & $(0.020)$ & $(0.020)$ & $(0.020)$ \\
\hline \multirow[t]{2}{*}{ civil servant } & $-0.065^{* * *}$ & $-0.081^{* * *}$ & ${ }^{*}-0.105^{* * *}$ & $-0.105^{* * *}$ & $-0.107^{* *}$ \\
\hline & $(0.009)$ & $(0.009)$ & $(0.040)$ & $(0.040)$ & $(0.045)$ \\
\hline \multirow[t]{2}{*}{ lives in city } & $0.023^{* * *}$ & $0.017^{* * *}$ & * 0.011 & 0.007 & 0.002 \\
\hline & $(0.006)$ & $(0.006)$ & $(0.008)$ & $(0.009)$ & $(0.008)$ \\
\hline
\end{tabular}

$<$ Table continues on next page $>$ 
Dependent Variable: Log(Hourly Wages)

\begin{tabular}{|c|c|c|c|c|c|}
\hline & $(1)$ & $(2)$ & $(3)$ & $(4)$ & $(5)$ \\
\hline \multicolumn{6}{|l|}{ Company Characteristics } \\
\hline \multirow{2}{*}{ product innovation } & & & 0.002 & 0.002 & 0.005 \\
\hline & & & $(0.008)$ & $(0.008)$ & $(0.008)$ \\
\hline \multirow[t]{2}{*}{ process innovation } & & & $0.057^{* * *}$ & $0.056^{* * *}$ & $0.036^{* * *}$ \\
\hline & & & $(0.008)$ & $(0.009)$ & $(0.008)$ \\
\hline \multirow[t]{2}{*}{ very good company performance } & & & $0.053^{* *}$ & $0.048^{* *}$ & $0.055^{* *}$ \\
\hline & & & $(0.023)$ & $(0.022)$ & $(0.023)$ \\
\hline \multirow[t]{2}{*}{ good company performance } & & & 0.008 & 0.004 & 0.013 \\
\hline & & & $(0.021)$ & $(0.021)$ & $(0.021)$ \\
\hline \multirow[t]{2}{*}{ rather bad company performance } & & & -0.012 & -0.016 & -0.009 \\
\hline & & & $(0.023)$ & $(0.023)$ & $(0.022)$ \\
\hline \multicolumn{6}{|c|}{ Workplace Characteristics: Measure of... } \\
\hline \multirow[t]{2}{*}{ analytic tasks } & & $0.110^{* * *}$ & $0.139^{* * *}$ & $0.139^{* * *}$ & $0.082^{* * *}$ \\
\hline & & $(0.012)$ & $(0.017)$ & $(0.017)$ & $(0.017)$ \\
\hline \multirow[t]{2}{*}{ interactive tasks } & & $0.185^{* * *}$ & $0.185^{* * *}$ & $0.186^{* * *}$ & $0.158^{* * *}$ \\
\hline & & $(0.011)$ & $(0.014)$ & $(0.014)$ & $(0.015)$ \\
\hline \multirow[t]{2}{*}{ routine cognitive tasks } & & $0.047^{* * *}$ & 0.023 & 0.022 & 0.008 \\
\hline & & $(0.014)$ & $(0.016)$ & $(0.016)$ & $(0.016)$ \\
\hline \multirow[t]{2}{*}{ routine manual tasks } & & $-0.032^{*}$ & $-0.067^{* * *}$ & $-0.064^{* * *}$ & $-0.038^{*}$ \\
\hline & & $(0.019)$ & $(0.020)$ & $(0.020)$ & $(0.022)$ \\
\hline \multirow[t]{2}{*}{ non-routine manual tasks } & & $-0.171^{* * *}$ & $-0.135^{* * *}$ & $-0.134^{* * *}$ & $-0.095^{* * *}$ \\
\hline & & $(0.012)$ & $(0.015)$ & $(0.015)$ & $(0.015)$ \\
\hline 77 occupation dummies & No & No & No & No & Yes \\
\hline 7 company size dummies & No & No & Yes & Yes & Yes \\
\hline dummies for manufacturing \& trade & No & No & Yes & Yes & Yes \\
\hline 10 dummies for West German states & No & No & No & Yes & Yes \\
\hline $\mathrm{R}^{2}$ & 0.300 & 0.323 & 0.383 & 0.385 & 0.437 \\
\hline Number of observations & 15951 & 13986 & 8037 & 8037 & 8001 \\
\hline
\end{tabular}

Employees with low levels of education working in large companies in the services sector are the base category. Heteroscedasticity-consistent standard errors are in parentheses. ****, **, *-indicate significance at the $1,5,10$ percent level. 


\section{Appendix B}

Table B1 displays the results of the matching estimations when occupations are not included in the specification estimating the propensity score. Column (1) shows that, using nearest neighbor matching, the average wage effect of computer use for employees who use computer is 7.8 percent. The coefficient is significant on the 1-percent level. In the matching, 3,461 controls are used to estimate the potential missing outcome of computer users had they not adopted computer technology 19 Owing to the restriction that only observations within the region of common support are used, there are 400 computer users who are not considered in the analysis. Column (2) shows the results when an Epanechnikov kernel is used in the matching process. This barely changes the magnitude of the ATT, but increases the precision of the estimate.

Table B3, last column, shows the means of the main individual characteristics of the computer non-users that are used as controls in the matching approach. It is evident that, although there is a convergence between treated and controls with respect to most of the observable characteristics, the difference in educational level is still significant. Therefore, columns (3) and (4) of Table B1 show estimates that, in addition to having close propensity scores, restrict matches to be within groups of employees with equal levels of education. This extension increases the number of computer users that are off the common support to 703. The estimate of the nearest neighbor matching declines to 6.2 percent, whereas the coefficient of the estimate that uses an Epanechnikov kernel increases to 8.2 percent. Both estimates are highly significant.

Table B2 shows the results when occupation dummies are included in the specification that estimates the propensity score. Both tables show that the estimated ATTs are very similar to those found when using regression based approaches (Table 3 , column 6 and 7 , respectively). This may be the case because (i) there is no common support problem,

\footnotetext{
${ }^{19}$ Owing to missing values in the matching variables, the sample reduces to 9,240 individuals $(5,779$ computer user and 3,461 computer non-user) in the matching specification.
} 
(ii) there is little heterogeneity in treatment effects or all the propensity scores are small, and (iii) there is no serious mis-specification in the no-treatment outcome [see Blundell, Dearden and Sianesi, 2003].

Figure B1 shows the kernel density estimates of the distribution of propensity scores for computer users and computer non-users. The two distributions greatly overlap. However, the results of the matching procedure reveal that 400 (703) of the 5,779 computer users are outside the region of common support. In this application imputing the values that are outside the common support by relying on a functional form assumption or discarding the computer users without similar counterfactuals from the analysis does not lead to different results.

The propensity scores in the analysis assume values between 0 and 1 . The mean is 0.64 and the median is 0.73 . This information does not suggest that propensity scores are particularly clustered at certain points in the distribution. 
Table B1: Results of the Propensity Score Matching (Occupation Dummies InCLUDED)

\begin{tabular}{lcccc}
\hline \hline \multicolumn{5}{c}{ Dependent Variable: $\log ($ Hourly } \\
& $(1)$ & $(2)$ & $(3)$ & $(4)$ \\
\hline \hline \multirow{2}{*}{ computer } & $0.078^{* * *}$ & $0.077^{* * *}$ & $0.062^{* * *}$ & $0.082^{* * *}$ \\
& $(0.032)$ & $(0.021)$ & $(0.025)$ & $(0.022)$ \\
\hline \multirow{2}{*}{ Number of Treated } & 5,379 & 5,379 & 5,076 & 5,076 \\
Number of Controls & 3,461 & 3,461 & 3,461 & 3,461 \\
\hline \hline
\end{tabular}

(1) shows the ATT of computer use using nearest neighbor matching (random draw version, bootstrapped standard errors using 100 replications). (2) shows the ATT using kernel matching (Epanechnikov kernel, bootstrapped standard errors using 100 replications). (3) shows the ATT of computer use using nearest neighbor matching (random draw version, bootstrapped standard errors using 100 replications) with the additional restriction that treated and controls have the same level of education. (4) shows the ATT using kernel matching (Epanechnikov kernel, bootstrapped standard errors using 100 replications) with the additional restriction that treated and controls have the same level of education. Only observations that are on the common support are used. The caliper is set to 0.001 . The propensity score is estimated using the level of formal education, age, age ${ }^{2}$, work experience, work experience ${ }^{2}$, interaction between work experience and education, workplace tasks, born in East Germany, ever unemployed, living in a city, woman, married, married woman, 8 company size dummies, 39 industry dummies, 3 dummies reflecting company performance, 79 occupation dummies, 10 dummies for West German states and a constant as regressors. 
Table B2: Results of the Propensity Score Matching (Without Occupation DumMIES)

\begin{tabular}{lcccc}
\hline \hline \multicolumn{5}{c}{ Dependent Variable: $\log$ (Hourly Wages) } \\
\hline \hline computer & $(1)$ & $(2)$ & $(3)$ & $(4)$ \\
& $0.137^{* * *}$ & $0.133^{* * *}$ & $0.146^{* * *}$ & $0.138^{* * *}$ \\
& $(0.028)$ & $(0.032)$ & $(0.025)$ & $(0.039)$ \\
\hline Number of Treated & 5,379 & 5,379 & 5,076 & 5,076 \\
Number of Controls & 3,461 & 3,461 & 3,461 & 3,461 \\
\hline \hline
\end{tabular}

(1) shows the ATT of computer use using nearest neighbor matching (random draw version, bootstrapped standard errors using 100 replications). (2) shows the ATT using kernel matching (Epanechnikov kernel, bootstrapped standard errors using 100 replications). (3) shows the ATT of computer use using nearest neighbor matching (random draw version, bootstrapped standard errors using 100 replications) with the additional restriction that treated and controls have the same level of education. (4) shows the ATT using kernel matching (Epanechnikov kernel, bootstrapped standard errors using 100 replications) with the additional restriction that treated and controls have the same level of education. Only observations that are on the common support are used. The caliper is set to 0.001 . The propensity score is estimated using the level of formal education, age, age ${ }^{2}$, work experience, work experience ${ }^{2}$, interaction between work experience and education, workplace tasks, born in East Germany, ever unemployed, living in a city, woman, married, married woman, 8 company size dummies, 39 industry dummies, 3 dummies reflecting company performance, 10 dummies for West German states and a constant as regressors. 
Table B3: Mean COMParison fOr COMPUter Users and COMPUTER Non-Users

\begin{tabular}{lccc}
\hline \hline & computer user & $\begin{array}{c}\text { computer non-user } \\
\text { prior to matching }\end{array}$ & $\begin{array}{c}\text { selected } \\
\text { controls }\end{array}$ \\
\hline high education level & 0.25 & $0.07^{*}$ & $0.17^{*}$ \\
medium education level & 0.69 & $0.72^{*}$ & $0.74^{*}$ \\
low education level & 0.06 & $0.21^{*}$ & $0.09^{*}$ \\
age & 39.99 & $40.29^{*}$ & 40.20 \\
experience & 20.04 & $21.52^{*}$ & $21.22^{*}$ \\
tenure & 12.37 & $10.82^{*}$ & 12.33 \\
ever unemployed & 0.26 & $0.34^{*}$ & 0.29 \\
married & 0.70 & $0.65^{*}$ & 0.70 \\
woman & 0.44 & 0.44 & 0.44 \\
civil servants & 0.15 & $0.05^{*}$ & 0.13 \\
born in East Germany & 0.03 & $0.05^{*}$ & 0.04 \\
\hline \hline
\end{tabular}

* indicates that the means differ with statistical significance of 5 percent in a two-tailed t-test between computer user and either computer nonuser prior to matching (column 3) or the selected computer non-user (last column).

$\S$ computer non-users who are selected by the matching procedure. 
Figure B1: Kernel Density Estimations of Propensity Scores for computer Users AND COMPUTER NON-USERS

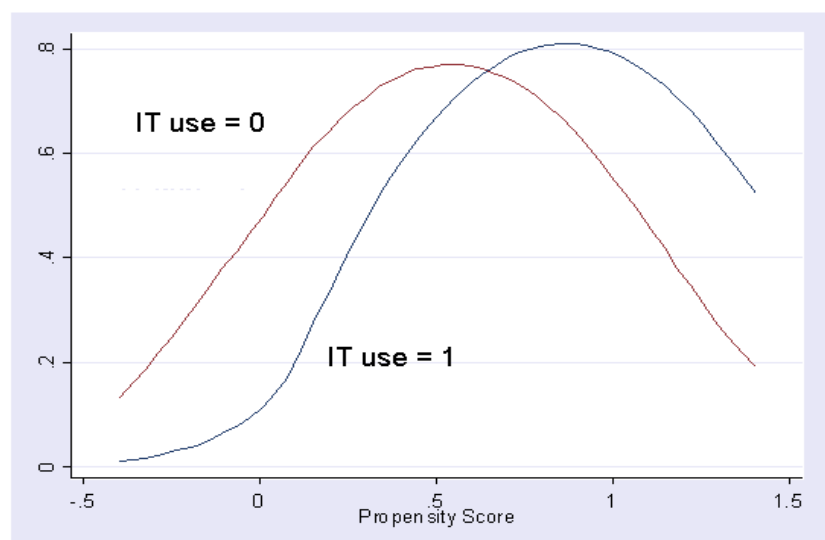




\section{References}

Abowd, J., Kramarz, F. and Margolis, D. (1999). High Wage Workers and High Wage Firms, Econometrica 67(2): 251-333.

Acemoglu, D. (2002). Technical Change, Inequality, and the Labor Market, Journal of Economic Literature 40: 7-72.

Autor, D., Katz, L. and Kearney, M. (2005a). Rising Wage Inequality: The Role of Composition and Prices, Working Paper 11628, NBER.

Autor, D., Katz, L. and Kearney, M. (2005b). Trends in U.S. Wage Inequality: Re-Assessing the Revisionists, Working Paper 11627, NBER.

Autor, D., Katz, L. and Krueger, A. (1998). Computing Inequality: Have Computers Changed the Labor Market?, Quarterly Journal of Economics 113(4): 1169-1213.

Autor, D., Levy, F. and Murnane, R. (2003). The Skill Content of Recent Technological Change: An Empirical Exploration, Quarterly Journal of Economics 118(4): 1279-1333.

Bell, B. (1996). Skill-Biased Technical Change and Wages: Evidence from a Longitudinal Data Set, Technical report, Nuffield College.

Blundell, R., Dearden, L. and Sianesi, B. (2003). Evaluating the Impact of Education on Earnings in the UK: Models, Methods and Results from the NCDS, Working Paper 03-20, IFS.

Brown, C. and Medoff, J. (1989). The Employer-Size Wage Effect, Journal of Political Economy 97(5): 1027-1059.

Chennells, L. and van Reenen, J. (1999). Has Technology Hurt Less Skilled Workers?, Working Paper Series W99/27, Institute for Fiscal Studies.

Dickens, W. and Katz, L. (1987). Inter-Industry Wage Differences and Industry Characteristics, in K. Lang and J. Leonard (eds), Unemployment and the Structure of the Labor Market, Basil Blackwell, New York, pp. 48-89.

DiNardo, J. and Pischke, J. (1997). The Returns to Computer Use Revisited: Have Pencils Changed the Wage Structure Too?, Quarterly Journal of Economics 112: 291-303. 
Dolton, P. and Makepeace, G. (2004). Computer Use and Earnings in Britain, Economic Journal 114: C117-C129.

Entorf, H. and Kramarz, F. (1997). Does Unmeasured Ability Explain the Higher Wages of New Technology Workers?, European Economic Review 41: 1489-1509.

Entorf, H., Gollac, M. and Kramarz, F. (1999). New Technologies, Wages, and Worker Selection, Journal of Labor Economics 17(3): 464-491.

Gibbons, R. and Katz, L. (1992). Does Unmeasured Ability Explain Inter-Industry Differentials, Review of Economic Studies 59(3): 515-535.

Goos, M. and Manning, A. (2007). Lousy and Lovely Jobs: The Rising Polarization of Work in Britain, Review of Economics and Statistics 89(1): 118-133.

Katz, L. and Autor, D. (1999). Changes in the Wage Structure and Earnings Inequality, in O. Ashenfelter and D. Card (eds), Handbook of Labor Economics, Elsevier Science, Amsterdam, pp. 1463-1555.

Krueger, A. (1993). How Computer have Changed the Wage Structure: Evidence from Microdata, 1984-1989, Quarterly Journal of Economics 108(1): 33-60.

Krueger, A. and Summers, L. (1987). Reflections on the Inter-Industry Wage Structure, in K. Lang and J. Leonard (eds), Unemployment and the Structure of the Labor Market, Basil Blackwell, New York, pp. 17-47.

Lang, K. (2002). Of Pencils and Computers, Technical report, Boston University.

Schmidt, C. and Zimmermann, K. (1991). Work Characteristics, Firm Size and Wages, Review of Economic Studies 73(4): 705-710.

Spitz-Oener, A. (2006). Technical Change, Job Tasks and Rising Educational Demands: Looking Outside the Wage Structure, Journal of Labor Economics 24(2): 235-270.

Wooldridge, J. (2002). Econometric Analysis of Cross Section and Panel Data, MIT Press, Cambridge, Massachusetts. 
Table 1: Assignment of Activities

\begin{tabular}{ll}
\hline \hline Classification & Tasks \\
\hline \hline non-routine analytic & researching, evaluating and planning, \\
& making plans, constructing, designing, sketching \\
& working out rules/regulations \\
& using and interpreting rules \\
\hline non-routine interactive & negotiating, lobbying, coordinating, organizing \\
& teaching or training \\
& selling, buying, advising customers, advertising \\
& entertaining or presenting \\
& employing or managing personnel \\
\hline routine cognitive & calculating, bookkeeping \\
& correcting of texts/data \\
& measuring of length/weight/temperature \\
& operating or controlling machines \\
& setting up machines \\
\hline routine manual & repairing or renovation houses/apartments/machines/vehicles \\
& restoring art/monuments \\
& serving or accomodating \\
\hline non-routine manual &
\end{tabular}


Table 2: OLS Regressions For The Effect Of Different Tools on Pay

\begin{tabular}{|c|c|c|c|c|}
\hline \multicolumn{5}{|c|}{ Dependent Variable: Log(Hourly Wages) } \\
\hline & Germany & Germany & Germany & Germany \\
\hline & 1979 & $1985-86$ & $1991-92$ & $1998-99$ \\
\hline \multicolumn{5}{|c|}{ A. Tools entered separately } \\
\hline \multirow[t]{2}{*}{ Computer } & 0.112 & 0.157 & 0.171 & 0.204 \\
\hline & $(0.010)$ & $(0.007)$ & $(0.006)$ & $(0.006)$ \\
\hline \multicolumn{5}{|c|}{ B. Tools entered together } \\
\hline \multirow[t]{2}{*}{ Computer } & 0.066 & 0.105 & 0.126 & 0.146 \\
\hline & $(0.010)$ & $(0.008)$ & $(0.007)$ & $(0.007)$ \\
\hline \multirow[t]{2}{*}{ Calculator } & 0.017 & 0.053 & 0.044 & 0.051 \\
\hline & $(0.008)$ & $(0.007)$ & $(0.007)$ & $(0.006)$ \\
\hline \multirow[t]{2}{*}{ Telephone } & 0.072 & 0.043 & 0.045 & -0.019 \\
\hline & $(0.007)$ & $(0.008)$ & $(0.008)$ & $(0.006)$ \\
\hline \multirow[t]{2}{*}{ Pen/Pencil } & 0.062 & 0.031 & 0.035 & 0.003 \\
\hline & $(0.007)$ & $(0.008)$ & $(0.008)$ & $(0.011)$ \\
\hline \multirow[t]{2}{*}{ Work while sitting } & 0.058 & 0.050 & - & 0.065 \\
\hline & $(0.007)$ & $(0.007)$ & - & $(0.006)$ \\
\hline
\end{tabular}

Standard errors are in parentheses. Source of columns 1-3: DiNardo and Pischke (1997, p. 299, Table III, 2nd part-left side). Column 4: own regressions. Similar to the specification in DiNardo and Pischke education, experience, experience squared, dummies for part-time, city, female, married, female*married, and for civil servants are included in the regressions. 
Table 3: OLS Regressions for the Effect of COMPUter on Wages

\begin{tabular}{lccccc|ccc}
\hline \hline \multicolumn{7}{c}{ Dependent Variable: Log(Hourly Wages $)$} & \multicolumn{2}{c}{} \\
\hline \hline Computer Use & $(1)$ & $(2)$ & $(3)$ & $(4)$ & $(5)$ & $(6)$ & $(7)$ \\
& $0.182^{* * *}$ & $0.123^{* * *}$ & $0.122^{* * *}$ & $0.122^{* * *}$ & $0.076^{* * *}$ & $0.120^{* * *}$ & $0.061^{* * *}$ \\
& $(0.005)$ & $(0.006)$ & $(0.008)$ & $(0.008)$ & $(0.010)$ & $(0.020)$ & $(0.024)$ \\
\hline Individual Characteristics & Yes & Yes & Yes & Yes & Yes & Yes & Yes \\
Workplace Characteristics & No & Yes & Yes & Yes & Yes & Yes & Yes \\
Company Characteristics & No & No & Yes & Yes & Yes & Yes & Yes \\
77 occupation dummies & No & No & No & No & Yes & No & Yes \\
7 company size dummies & No & No & Yes & Yes & Yes & Yes & Yes \\
Dummies for manufacturing \& trade & No & No & Yes & Yes & Yes & Yes & Yes \\
10 dummies for West German states & No & No & No & Yes & Yes & Yes & Yes \\
\hline Computer $*[x-E(x)]$ & No & No & No & No & No & Yes & Yes \\
\hline $\mathrm{R}^{2}$ & 0.348 & 0.340 & 0.399 & 0.401 & 0.443 & 0.410 & 0.455 \\
Number of observations & 18547 & 15266 & 8936 & 8936 & 8897 & 8936 & 8897 \\
\hline \hline
\end{tabular}

Employees with low levels of education working in large companies in the services sector are the base category. Heteroscedasticity-consistent standard errors are in parentheses in column (1)-(5). Column (6) and (7): Computer $*[x-E(x)]$ means that the specification includes interaction terms between computer use and all the level variables $X$, where all the $X$ had previously been demeaned by the sample averages. Bootstrapped standard errors using 100 resamples. $*^{* *},{ }^{* *},{ }^{*}$-indicate significance at the 1 , 5,10 percent level. 
Table 4: Selected Interaction Terms

\begin{tabular}{|c|c|}
\hline \multicolumn{2}{|l|}{ Dependent Variable: Log(Hourly Wages) } \\
\hline \multirow[t]{2}{*}{ high educ. level $*$ computer } & $0.136^{* * *}$ \\
\hline & $(0.056)$ \\
\hline \multirow[t]{2}{*}{ medium educ. level $*$ computer } & -0.003 \\
\hline & $(0.029)$ \\
\hline \multirow[t]{2}{*}{ woman $*$ computer } & 0.042 \\
\hline & $(0.028)$ \\
\hline \multirow[t]{2}{*}{ non-routine analytic tasks $*$ computer } & $0.077^{* *}$ \\
\hline & $(0.040)$ \\
\hline \multirow[t]{2}{*}{ non-routine interactive tasks $*$ computer } & -0.034 \\
\hline & $(0.031)$ \\
\hline \multirow[t]{2}{*}{ routine cognitive tasks $*$ computer } & 0.015 \\
\hline & $(0.028)$ \\
\hline \multirow[t]{2}{*}{ routine manual tasks $*$ computer } & 0.011 \\
\hline & $(0.037)$ \\
\hline \multirow[t]{2}{*}{ non-routine manual tasks * computer } & $-0.098^{* * *}$ \\
\hline & $(0.028)$ \\
\hline \multirow[t]{2}{*}{ experience $*$ computer } & $0.006^{* * *}$ \\
\hline & $(0.002)$ \\
\hline \multirow[t]{2}{*}{ experience $^{2} *$ computer } & -0.000 \\
\hline & $(0.000)$ \\
\hline
\end{tabular}

Note: Results based on specification in Table 3 , column $(6)$. 
Table 5: OLS Regressions for the Effect of Pencil Use on Wages

\begin{tabular}{|c|c|c|c|c|c|}
\hline \multicolumn{6}{|c|}{ Dependent Variable: Log(Hourly Wages) } \\
\hline & (1) & $(2)$ & $(3)$ & $(4)$ & $(5)$ \\
\hline \multirow[t]{2}{*}{ Pencil Usage } & $0.033^{* * *}$ & 0.016 & 0.016 & 0.016 & 0.005 \\
\hline & $(0.010)$ & $(0.011)$ & $(0.013)$ & $(0.013)$ & $(0.013)$ \\
\hline Individual Characteristics & Yes & Yes & Yes & Yes & Yes \\
\hline Workplace Characteristics & No & Yes & Yes & Yes & Yes \\
\hline Company Characteristics & No & No & Yes & Yes & Yes \\
\hline 77 occupation dummies & No & No & No & No & Yes \\
\hline 7 company size dummies & No & No & Yes & Yes & Yes \\
\hline dummies for manufacturing \& trade & No & No & Yes & Yes & Yes \\
\hline 10 dummies for West German states & No & No & No & Yes & Yes \\
\hline $\mathrm{R}^{2}$ & 0.300 & 0.323 & 0.383 & 0.385 & 0.437 \\
\hline Number of observations & 15951 & 13986 & 8037 & 8037 & 8001 \\
\hline
\end{tabular}

Employees with low levels of education working in large companies in the services sector are the base category. Heteroscedasticity-consistent standard errors are in parentheses. ***, **, *-indicate significance at the 1, 5, 10 percent level. 
Table 6: Changes in Computer Use, Pencil Use and in Skill Requirements

\begin{tabular}{|c|c|c|c|c|c|}
\hline & Analytic & Interactive & Routine & Routine & Non-routine \\
\hline & Tasks & Tasks & Cognitive Tasks & Manual Tasks & Manual Tasks \\
\hline \multicolumn{6}{|c|}{ Panel A } \\
\hline \multirow[t]{2}{*}{$\Delta$ computer use } & $0.086^{* * *}$ & $0.188^{* * *}$ & $-0.312^{* * *}$ & $-0.561^{* * *}$ & 0.128 \\
\hline & $(0.032)$ & $(0.031)$ & $(0.105)$ & $(0.148)$ & $(0.085)$ \\
\hline \multirow[t]{2}{*}{ dummy 1985/86-1991/92 } & $-6.160 * * *$ & $3.536^{* *}$ & -1.960 & -2.462 & $-1.67^{* * *}$ \\
\hline & $(1.129)$ & $(1.767)$ & $(3.098)$ & $(7.712)$ & $(0.401)$ \\
\hline \multirow[t]{2}{*}{ dummy 1991/92-1998/99 } & $-7.987^{* * *}$ & $8.915^{* * *}$ & $16.394^{* *}$ & -7.436 & $-1.147^{* *}$ \\
\hline & $(1.381)$ & $(1.440)$ & $(7.726)$ & $(7.065)$ & $(0.520)$ \\
\hline$R^{2}$ & 0.183 & 0.337 & 0.079 & 0.131 & 0.065 \\
\hline Number of observations: & \multicolumn{5}{|c|}{237} \\
\hline \multicolumn{6}{|c|}{ Panel B } \\
\hline \multirow[t]{2}{*}{$\Delta$ pencil use } & 0.025 & $-0.112^{* * *}$ & $0.913^{* * *}$ & 0.074 & $-0.320^{* * *}$ \\
\hline & $(0.025)$ & $(0.023)$ & $(0.130)$ & $(0.059)$ & $(0.077)$ \\
\hline \multirow[t]{2}{*}{ dummy 1985/86-1991/92 } & $-0.604^{* * *}$ & $0.677^{* * *}$ & $-1.987^{* * *}$ & -0.750 & $-1.036^{* * *}$ \\
\hline & $(0.139)$ & $(0.195)$ & $(0.407)$ & $(0.782)$ & $(0.424)$ \\
\hline \multirow[t]{2}{*}{ dummy 1991/92-1998/99 } & $-0.821^{* * *}$ & $1.488^{* * *}$ & $-2.106^{* * *}$ & $-1.522^{* *}$ & 0.174 \\
\hline & $(0.202)$ & $(0.165)$ & $(0.829)$ & $(0.699)$ & $(0.591)$ \\
\hline$R^{2}$ & 0.150 & 0.279 & 0.431 & 0.028 & 0.128 \\
\hline
\end{tabular}

Number of observations: 237

Source of Panel A: Spitz-Oener [2006], Table 6. Robust standard errors are in parentheses; regressions are weighted by the number of individuals within occupation group; ***,**,*-indicate significance at the 1, 5, 10 percent level. 


\begin{tabular}{|c|c|c|c|c|c|}
\hline \multicolumn{6}{|c|}{ Dependent Variable: Log(Hourly Wages) } \\
\hline & $(1)$ & $(2)$ & (3) & $(4)$ & $(5)$ \\
\hline \multirow[t]{2}{*}{ Computer Use } & \multicolumn{3}{|c|}{$0.144^{* * *}$} & $0.122^{* * *}$ & $0.146^{* * *}$ \\
\hline & \multicolumn{3}{|c|}{$(0.006)$} & $(0.008)$ & $(0.014)$ \\
\hline \multirow[t]{2}{*}{ non-routine analytic } & $0.239^{* * *}$ & $0.195^{* * *}$ & $0.193^{* * *}$ & $0.120^{* * *}$ & $0.058^{*}$ \\
\hline & $(0.013)$ & $(0.013)$ & $(0.016)$ & $(0.016)$ & $(0.035)$ \\
\hline \multirow[t]{2}{*}{ non-routine interactive } & $0.357^{* * *}$ & $0.298^{* * *}$ & $0.249^{* * *}$ & $0.155^{* * *}$ & $0.147^{* * *}$ \\
\hline & $(0.011)$ & $(0.012)$ & $(0.014)$ & $(0.014)$ & $(0.025)$ \\
\hline \multirow[t]{2}{*}{ routine cognitive } & $0.103^{* * *}$ & $0.075^{* * *}$ & 0.022 & 0.004 & -0.001 \\
\hline & $(0.014)$ & $(0.013)$ & $(0.014)$ & $(0.014)$ & $(0.018)$ \\
\hline \multirow[t]{2}{*}{ routine manual } & $-0.065^{* * *}$ & * -0.008 & $-0.101^{* * *}$ & $-0.037^{* *}$ & -0.015 \\
\hline & $(0.018)$ & $(0.018)$ & $(0.019)$ & $(0.018)$ & $(0.024)$ \\
\hline \multirow[t]{2}{*}{ non-routine manual } & $-0.241^{* * *}$ & ${ }^{*}-0.187^{* * *}$ & $-0.160^{* * *}$ & $-0.095^{* * *}$ & * -0.027 \\
\hline & $(0.012)$ & $(0.012)$ & $(0.014)$ & $(0.014)$ & $(0.023)$ \\
\hline \multirow[t]{2}{*}{ non-routine analytic*Computer Use } & & & & & $0.075^{* *}$ \\
\hline & & & & & $(0.039)$ \\
\hline \multirow[t]{2}{*}{ non-routine interactive*Computer Use } & & & & & 0.012 \\
\hline & & & & & $(0.030)$ \\
\hline \multirow[t]{2}{*}{ routine cognitive*Computer Use } & & & & & 0.014 \\
\hline & & & & & $(0.028)$ \\
\hline \multirow[t]{2}{*}{ routine manual*Computer Use } & & & & & -0.032 \\
\hline & & & & & $(0.037)$ \\
\hline \multirow[t]{2}{*}{ non-routine manual*Computer Use } & & & & & $-0.103^{* *}$ \\
\hline & & & & & $(0.028)$ \\
\hline Individual Characteristics & No & No & Yes & Yes & Yes \\
\hline Company Characteristics & No & No & Yes & Yes & Yes \\
\hline 7 company size dummies & No & No & Yes & Yes & Yes \\
\hline dummies for manufacturing \& trade & No & No & Yes & Yes & Yes \\
\hline 10 dummies for West German states & No & No & Yes & Yes & Yes \\
\hline $\mathrm{R}^{2}$ & 0.112 & 0.136 & 0.342 & 0.363 & 0.365 \\
\hline Number of observations & 15679 & 15679 & 8897 & 8897 & 8897 \\
\hline
\end{tabular}

Note: Specification in column (4) is identical t36specification in Table 3, column (4). 